\title{
Two-Generation Diet-Induced Obesity Model Producing Mice With Increased Amount of Body Fat in Early Adulthood
}

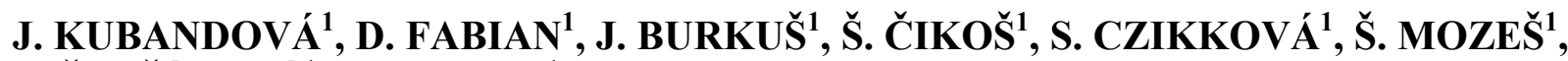 \\ Z. ŠEFČÍKOVÁ ${ }^{1}$, J. KOPPEL $^{1}$ \\ ${ }^{1}$ Institute of Animal Physiology, Slovak Academy of Science, Košice, Slovakia
}

Received April 4, 2013

Accepted August 15, 2013

On-line November 1, 2013

\begin{abstract}
Summary
The aim of our study was to develop a model producing obese mice in early adulthood (4-6 weeks) based on their over-nutrition during fetal and early postnatal development. The fertilized dams of the parental generation were fed the standard diet supplemented with high-energy nutritional product Ensure Plus during gestation and lactation. Delivered weanlings were then fed with standard or supplemented diet and assessed for body fat deposits using EchoMRI at the time of early and late adulthood. Maternal over-feeding during the period before weaning had the most significant effect on obesity development in the filial generation. In weanlings, significantly higher body fat deposits and average body weight were recorded. Later, further significant increase in percentage of body fat in both male and female mice was observed. Withdrawal of the Ensure Plus supplement caused a decrease in the percentage of body fat in part of the filial generation. In offspring fed the standard diet, higher fat deposits persisted till the time of late adulthood. We conclude that this diet-induced obesity model might be used in exploration of the effects of elevated body fat on physiological functions of various organ systems during juvenile and early adulthood periods of life of a human being.
\end{abstract}

\section{Key words}

Diet-induced obesity • Fat deposits • Body weight

\section{Corresponding author}

Janka Kubandová, Institute of Animal Physiology, Slovak Academy of Science, Šoltésovej 4/6, 04001 Košice, Slovak Republic. E-mail: kubandova@saske.sk

\section{Introduction}

Increased food consumption surpassing the energy requirements of the organism is usually manifested by excessively increased body fat stores and represents a growing human health problem (Mozeš et al. 2004). Insights into the etiology of human obesity have arisen from the study of animal models. Animal models of obesity are also important for the development of future treatments of obesity (Carroll et al. 2004).

The mouse is very useful rodents for studying obesity. Mice are small and easy to handle and are inexpensive to propagate and maintain (Carroll et al. 2004).

Obesity is a phenotype that is readily observable, and mice with naturally arising mutations causing this phenotype have been extensively described (Perry et al. 1994, Zhang et al. 1994, Tartaglia et al. 1995, Carroll et al. 2004). One of the early models identified is the $o b / o b$ mouse, discovered in 1950 (Ingalls et al. 1950). The $o b / o b$ mouse produces no leptin, due to a gene mutation, and has a recessive genetic obesity that results in sterile adult mice with over $50 \%$ fat (Houseknecht et al. 1998). A close relative, $d b / d b$, was later discovered (Hummel et al. 1966). The obese (ob) and diabetes (db) single-gene mutations have an almost identical phenotype when bred on the same genetic background: juvenile onset of severe obesity arising from excessive food intake or hyperphagia, insulin resistance, glucose intolerance and diabetes. A similar phenotype was observed in the Agouti yellow (Ay) mouse, except for the adult onset of more moderate obesity (Chagnon and Bouchard 1996). However, none of these has led to an explanation of any 
prevalent form of human obesity (Houseknecht et al. 1998).

Diet-induced obesity models are believed to most appropriately mimic the development of obesity in humans (Mercer and Archer 2008). The diet-induced obesity model represents the crossroads of nature and nurture. Diet composition and genetic background interact to unmask the underlying weight gain phenotype, which is only manifested if animals are exposed to a high fat or high energy diet (Levin and Kessey 1998). However, diet-induced obesity models are widely criticized because they do not attain the extreme obesity seen in leptin-deficient genetic models (Modak and Mukhopadhya 2011). Some of the modeling techniques have only short-term effects on physical conditions, and it usually take several weeks to get results, while the mice continue aging and are evaluated not at the most optimal period. Such models cannot be used for example in reproductive studies, which are predominantly performed on mice in early adulthood (Fabian et al. 2007), since aging is accompanied with significant decrease in reproductive abilities of animals as well as decrease in embryo quality (Jurisicova et al. 1998).

The aim of our study was to develop a dietetic model producing obese mice in early sexual adulthood (4 to 6 weeks old) based on their relatively short-term over-nutrition during embryonic, fetal and early postnatal development. A dietary nutritional product named Ensure Plus (Abbot Laboratories, Netherlands) was used as a high-energy source for pregnant dams and a portion of their offspring. Our results should support the hypothesis that altered nutritional conditions in prenatal and early life may have persistent effects on body weight and body condition.

\section{Methods}

All experiments were performed on mice of the outbred ICR strain (Velaz, Prague, Czech Republic) and whole experimental design was repeated two times. Mice were housed in plexiglass cages under standard conditions (temperature $22 \pm 2{ }^{\circ} \mathrm{C}$, humidity $55 \pm 5 \%$, 12:12-h light-dark cycle with lights on at 5:00, with free access to food and water). All animal experiments were reviewed and approved by the Ethical Committee for animal experimentation of the Institute of Animal Physiology, approved by State Veterinary and Food Administration of the Slovak Republic, and were performed in accordance with Slovakian legislation based on EC Directive 86/609/EEC on the protection of animals used for experimental and other scientific purposes.

\section{Nutrition of pregnant dams (Parental generation)}

Adult female mice (4 weeks old) underwent reproductive-cycle synchronization treatment with equine chorionic gonadotropin (eCG 5 IU ip; Folligon, Intervet International, Boxmeer, Holland), followed $47 \mathrm{~h}$ later by administration of human chorionic gonadotropin (hCG 4 IU ip; Pregnyl, Organon, Oss, Holland). Females were mated with males of the same strain overnight and mating was confirmed by identification of a vaginal plug.

Fertilized mice were randomly divided into control $(\mathrm{C}, \mathrm{n}=7)$ and experimental $(\mathrm{EX}, \mathrm{n}=12)$ groups (Fig. 1).

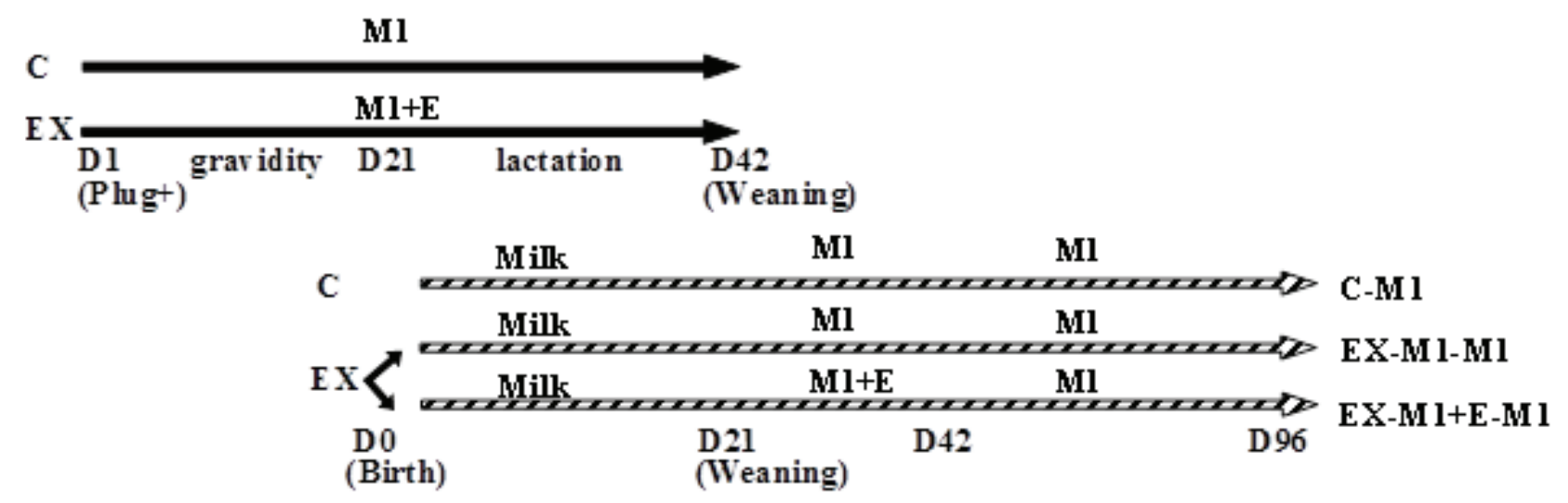

Fig. 1. Scheme of experimental design. C: parental mice in the control group on standard laboratory diet; EX: parental mice in experimental group on the standard diet with addition of Ensure Plus during gestation and lactation; M1: standard laboratory diet; $\mathrm{M} 1+\mathrm{E}$ : standard laboratory diet with addition of Ensure Plus; C-M1: the F1 animals in the control group on the standard diet; EX-M1M1: the F1 animals in the experimental group on the standard diet; EX-M1+E-M1: the F1 animals in the experimental group on the standard diet with addition of Ensure Plus for the first 3 weeks after weaning;

$\longrightarrow$ : parental $(P)$ generation; $\cdots$ : filial (F1) generation 
During the gestation period (21 days) and the lactation period (21 days from birth of pups to weaning), dams in the control group (C) were fed the standard pellet diet (M1, Řicmanice, Czech Republic; 3.2 cal $/ \mathrm{g}$, with $26.3 \%$ energy as protein, $9.5 \%$ as fat, and $64.2 \%$ as carbohydrate), and dams in the experimental group (EX) were fed the standard M1 diet with the addition of highenergy nutritional product Ensure Plus ad libitum. Ensure Plus is a liquid solution that contains $1.5 \mathrm{cal} / \mathrm{ml}(15 \%$ of the metabolizable energy content as protein, $28 \%$ as fat and $57 \%$ as carbohydrate).

The result of this diet was the production of offspring with a high predisposition for the development of obesity in the time of sexual adulthood (Day 42 of age). The litter size was adjusted on the first day after birth up to 10 pups per nest.

\section{Nutrition of offspring (F1 generation)}

Following procedures were performed on 18 pups delivered from 2 control dams and 39 pups delivered from 4 over-fed experimental dams.

After weaning (Day 21), F1 animals from control dams were fed the standard pellet diet (C-M1). The F1 animals bred in the experimental group were allocated into two groups and continued on the standard diet (EX-M1-M1) or a diet with the addition of Ensure Plus (EX-M1+E-M1) for 3 weeks. Between Day 42 and 96 of age, F1 mice in all control and experimental groups were fed only the standard diet without addition of Ensure Plus. The experiment was finished at Day 96 of the F1 animals' age.

\section{Evaluation of basic physiological parameters}

In both, parental and filial generations, body weight, standard diet intake, Ensure Plus intake and water intake were measured at regular intervals. Energy intake was calculated as M1 (g) / number of mice in control group $\mathrm{x}$ 3.2, and as M1 (g) /number of mice in experimental group $\times 3.2+$ Ensure Plus intake of the experimental group $(\mathrm{ml})$ / number of experimental mice $\mathrm{x}$ 1.5 .

Furthermore, mice were individually scanned using MRI (Echo MRI, Whole Body Composition Analyser, Echo Medical System, Houston, Texas) for the evaluation of the exact amount of body fat deposits. Percentage of body fat was calculated as body fat (g)/body weight (g) x 100. MRI scanning was performed on Days 21, 42 and 96 of F1 animals' age.

\section{Analysis of blood parameters}

At Day 42, a cohort of F1 mice from C-M1 $(n=32)$ and EX-M1-M1group $(n=32)$ delivered from another 3 control and 3 over-fed experimental dams were decapitated for blood collection. Blood was centrifuged, and serum was transferred to clean vials for storage at $-80{ }^{\circ} \mathrm{C}$ until the day of assay. Concentrations of hormones (leptin, adiponectin and insulin) were quantified by commercial ELISA kits: Mouse leptin 96well plate assay, Mouse adiponectin 96-well plate assay, Rat/Mouse Insulin 96-well plate assay (Millipore, Billerica, MA). Concentrations of glucose, cholesterol and triglycerides were quantified by Architect $c$ Systems and system Aeroset (Abbott laboratories).

\section{Statistical analysis}

Statistical analysis was performed using Statistica (StatSoft, USA). Results were expressed as mean values \pm SEM. Student's $t$-test was used to detect differences in average body fat, body weight, caloric intake, M1 intake and water intake in dams during gestation and lactation periods, in the average number of pups at the day of birth, body fat and body weight of pups at weaning day (Day 21) and leptin and adiponectin concentration, insulin concentration and concentration of glucose, cholesterol and triglycerides of offspring. Following ANOVA Tukey's post hoc test was used to detect differences in average weight of pups, body fat, caloric intake, M1-diet intake, water intake (Day 42 and Day 96). Differences of $\mathrm{P}<0.05$ were considered as significant.

\section{Results}

The effect of over-nutrition on pregnant dams (Parental generation)

As shown in Table 1, the addition of Ensure Plus to the animal diet significantly increased mean caloric intake of experimental dams during both gestation and lactation periods, although their intake of water and standard M1-diet was lower when compared to controls. As shown in Table 2, the dietary manipulation did not affect somatic development of dams. Females in both groups displayed similar body weight and amount of fat deposits at the day of fertilization, delivery and weaning ( $\mathrm{P}>0.05$ for all cases). Ensure Plus-supplemented dietreceiving dams delivered a significantly higher number of pups when compared to controls (14.42 \pm 0.87 vs. $10.29 \pm 0.95$ per dam at average, $\mathrm{P}<0.01)$. However, 
Table 1. Feeding parameters of dams fed either the control or high-energy diet during gestation and lactation periods.

\begin{tabular}{|c|c|c|c|}
\hline & Parameter per mouse, per week & Control dams & Experimental dams \\
\hline \multirow[t]{4}{*}{ Gestation period (D1-D21) } & Mean caloric intake (kcal) & $142.40 \pm 6.91$ & $167.68 \pm 12.26^{*}$ \\
\hline & M1-diet intake $(g)$ & $44.50 \pm 2.16$ & $24.12 \pm 2.80 *$ \\
\hline & ENSURE PLUS intake $(\mathrm{ml})$ & 0.00 & $60.33 \pm 0.40$ \\
\hline & Water intake $(\mathrm{ml})$ & $55.77 \pm 2.79$ & $29.38 \pm 4.03 * *$ \\
\hline \multirow[t]{4}{*}{ Lactation period (D21-D42) } & Mean caloric intake ( $k c a l)$ & $415.55 \pm 9.14$ & $529.00 \pm 3.40^{*}$ \\
\hline & M1-diet intake (g) & $129.86 \pm 2.86$ & $83.75 \pm 2.11 * * *$ \\
\hline & ENSURE PLUS intake (ml) & 0.00 & $174.00 \pm 0.13$ \\
\hline & Water intake $(\mathrm{ml})$ & $160.00 \pm 8.73$ & $100.25 \pm 9.15^{* *}$ \\
\hline
\end{tabular}

Values are means \pm SEM. Significance of difference from control group: $* \mathrm{P}<0.05 ; * * \mathrm{P}<0.01 ; * * * \mathrm{P}<0.001$

Table 2. Somatic development of dams fed either the control or high-energy diet.

\begin{tabular}{llll}
\hline & Parameter per mouse & Control dams & Experimental dams \\
\hline D1 (Fertilization) & Bodyweight $(g)$ & $24.60 \pm 0.22$ & $24.80 \pm 0.33$ \\
& Bodyfat $(\%)$ & $6.82 \pm 0.29$ & $6.86 \pm 0.26$ \\
D21 (Delivery) & Bodyweight $(g)$ & $45.71 \pm 3.64$ & $46.19 \pm 3.56$ \\
& Bodyfat $(\%)$ & $\mathrm{NM}$ & $\mathrm{NM}$ \\
D42 (Weaning) & Bodyweight $(g)$ & $37.70 \pm 0.65$ & $39.17 \pm 0.88$ \\
& Bodyfat $(\%)$ & $6.48 \pm 0.30$ & $7.46 \pm 0.40$ \\
\hline
\end{tabular}

Values are means \pm SEM. (NM: not measured)

higher incidence of stillborn pups was observed in them too $(5.78 \pm 2.27 \%$ vs. $0.00 \%)$.

The effect of maternal over-nutrition on offspring (F1 generation)

To avoid potential disruption of social interaction between mother and offspring, no somatic parameters were evaluated in any newborn pups (at Day 0).

At weaning (Day 21 after birth), the percentage of body fat in pups delivered from over-fed dams (experimental group) was significantly higher than in pups delivered from control dams (9.59 \pm 0.22 vs. $8.63 \pm 0.29 \% ; \mathrm{P}<0.05$; Fig. 2A). Increase in fat deposits was recorded predominantly in males. At the same day, experimental group pups also showed significantly higher body weight when compared to the control F1 group $(12.12 \pm 0.21 \mathrm{~g}$ vs. $9.68 \pm 0.41 \mathrm{~g}$ at average; $\mathrm{P}<0.001$; Fig. 3A).

During the first three weeks after weaning (between Days 21 and 42 of the age), a portion of pups delivered from over-fed dams (EX-M1+E-M1) was fed the diet supplemented with Ensure Plus. As shown in Table 3, average week caloric intake in this group $(100.12 \pm 2.53 \mathrm{kcal})$ was slightly higher than in control pups fed the standard diet $(77.57 \pm 7.39 \mathrm{kcal})$, although the difference reached statistical significance only in the male part of population. Caloric intake in the EX-M1+E-M1 group was also slightly higher than in the EX-M1-M1 group (pups delivered from over-fed dams on standard diet only), but no significant differences were observed between experimental groups.

At Day 42 values of body fat in the EX-M1-M1 and EX-M1+E-M1 groups were significantly higher in all cases than in the control group $(10.58 \pm 0.46$ and $11.30 \pm 0.56 \quad$ vs. $\quad 8.29 \pm .0 .32 \% ; \quad \mathrm{P}<0.01, \quad \mathrm{P}<0.001$ respectively). The means of body fat for both sexes are shown in Figure 2 A,B,C.

During the following two months (between Days 42 and 96), the mice in all groups were fed the standard diet only. In this period, diet intake (at libitum feeding) was significantly increased in the EX-M1-M1 group (Table 4). 

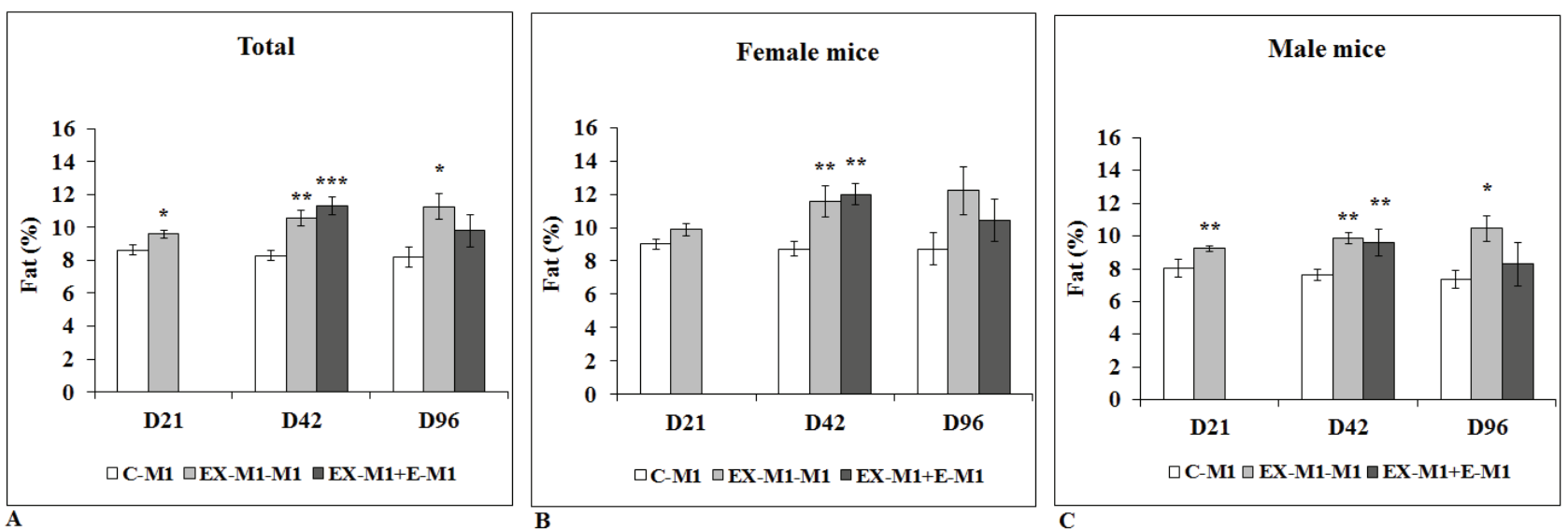

Fig. 2. Body fat in offspring. Figure $\mathbf{2 A}$ represents percentage of body fat in pups delivered from over-fed dams and control dams at weaning day (D21 after birth), at day 42 and at day 96 . The means of body fat for female and male pups are shown in Figure $\mathbf{2 B}$ and 2C respectively. Values are means \pm SEM. Statistical differences between experimental groups and the corresponding control group were determined using Student's $t$-test (Day 21 ) and ANOVA+Tukey's test (Day 42 and Day 96 ): $* \mathrm{P}<0.05 ; * * \mathrm{P}<0.01 ; * * * \mathrm{P}<0.001$. C-M1: the F1 animals in the control group on the standard diet; EX-M1-M1: the F1 animals in the experimental group on the standard diet; EX-M1+E-M1: the F1 animals in the experimental group on the standard diet with addition of Ensure Plus for the first 3 weeks.
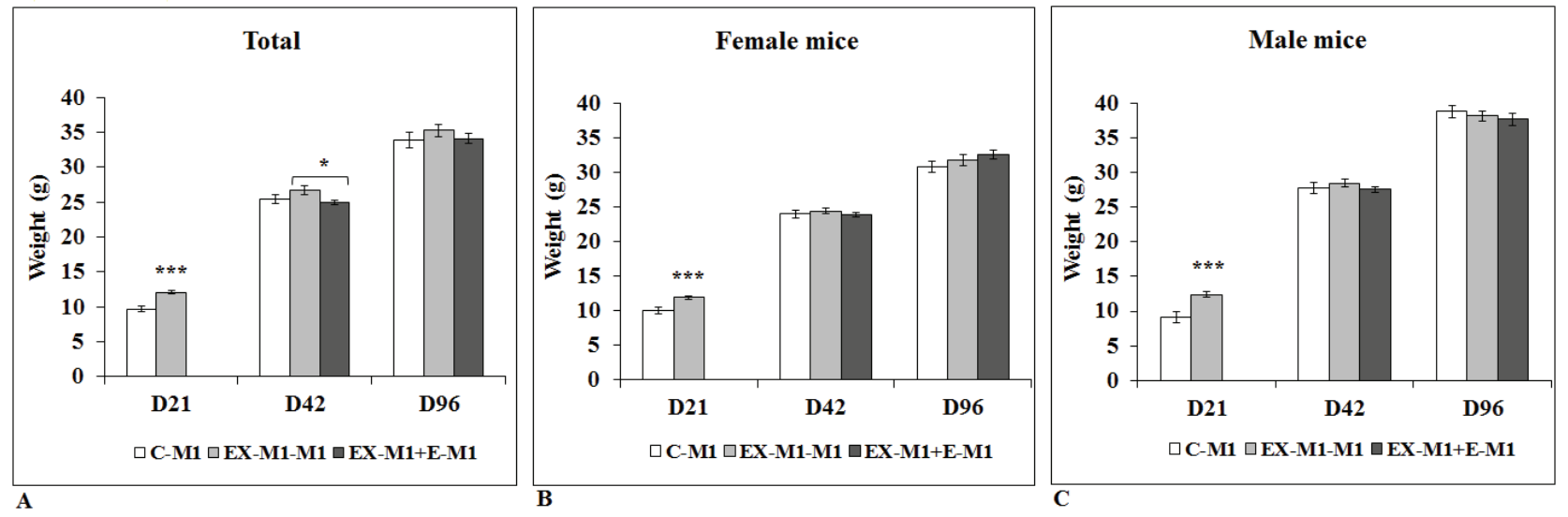

Fig. 3. Body weight in offspring. Figure $\mathbf{3 A}$ represents body weight value in pups delivered from over-fed dams and control dams at weaning day (D21 after birth), at day 42 and at day 96 . The means of body weight for female and male mice are shown in Figure 3B and 3C. Values are means \pm SEM. Statistical differences between experimental groups and the corresponding control group were determined using Student's $t$-test (Day 21) and ANOVA+Tukey's test (Day 42 and Day 96): $* \mathrm{P}<0.05 ; * * * \mathrm{P}<0.001$. C-M1: the F1 animals in the control group on the standard diet; EX-M1-M1: the F1 animals in the experimental group on the standard diet; EX-M1+EM1: the F1 animals in the experimental group on the standard diet with addition of Ensure Plus for the first 3 weeks.

At Day 96 after birth, significantly higher deposits of body fat were observed only in the experimental group fed the standard diet $(11.25 \pm 0.78$ vs. $8.20 \pm 0.62 \%$; $\mathrm{P}<0.05$; Fig. $2 \mathrm{~A}$ ).

At Days 42 and 96 there were no significant differences in body weight between experimental groups (EX-M1-M1 and EX-M1+E-M1) and the control group (C-M1). Selective evaluation of female and male mice showed identical results (Fig. 3B, 3C). Comparison of the two experimental groups showed minor differences at Day 42 (slightly increased body weight in the EX-M1M1 group).

\section{Blood parameters in $F 1$ offspring}

As shown in Table 5, in blood serum of F1 mice in experimental group fed standard diet significantly higher levels of glucose $(8.92 \pm 0.22 \mathrm{mmol} / \mathrm{ml}$ vs. $8.34 \pm 0.15 \mathrm{mmol} / \mathrm{ml} ; \quad \mathrm{P}<0.05) \quad$ and adiponectin $(7470.8 \pm 812.92 \mathrm{ng} / \mathrm{ml}$ vs. $9878.3 \pm 920.11 \mathrm{ng} / \mathrm{ml} ; \mathrm{P}<0.05)$ were found when compared to control group mice at Day 42. Although some of other evaluated parameter also showed tendency to increase, there were found no significant differences in leptin, insulin, cholesterol and triglycerides concentrations between experimental group (EX-M1-M1) and control group (C-M1). 
Table 3. Feeding parameters of pups (F1 animals) fed either the standard (C-M1 group, EX-M1-M1 group) or high-energy diet (EX$\mathrm{M} 1+\mathrm{E}-\mathrm{M} 1$ group) during the first 3 weeks after weaning.

\begin{tabular}{llll}
\hline $\begin{array}{l}\text { Parameter per mouse, } \\
\text { per week }\end{array}$ & $\begin{array}{l}\text { Control group } \\
\mathbf{n}=\mathbf{1 8}\end{array}$ & $\begin{array}{l}\text { EX-M1-M1 group } \\
\mathbf{n}=\mathbf{1 9}\end{array}$ & $\begin{array}{l}\text { EX-M1+E-M1 group } \\
\mathbf{n = 2 0}\end{array}$ \\
\hline $\begin{array}{l}\text { Mean caloric intake }(\mathrm{kcal}) \\
\begin{array}{l}\text { Females } \\
\text { Males }\end{array}\end{array}$ & $\begin{array}{l}77.57 \pm 7.39 \\
73.99 \pm 10.01\end{array}$ & $\begin{array}{l}86.68 \pm 8.71 \\
77.87 \pm 9.09\end{array}$ & $\begin{array}{l}100.12 \pm 2.53 \\
92.96 \pm 1.85 \\
116.81 \pm 4.16^{*}\end{array}$ \\
\hline $\begin{array}{l}84.72 \pm 9.53 \\
\text { Ml-diet intake }(\mathrm{g})\end{array}$ & $24.24 \pm 2.31$ & $91.15 \pm 9.43$ & $14.97 \pm 0.66$ \\
Females & $23.12 \pm 3.13$ & $27.09 \pm 2.72$ & $13.38 \pm 0.13$ \\
Males & $26.48 \pm 2.98$ & $24.33 \pm 2.84$ & $18.67 \pm 2.27$ \\
\hline $\begin{array}{l}\text { Ensure Plus intake }(\mathrm{ml}) \\
\text { Females }\end{array}$ & 0.00 & $28.48 \pm 2.95$ & $34.82 \pm 1.35$ \\
Males & 0.00 & 0.00 & $33.4 \pm 1.80$ \\
\hline Water intake $(\mathrm{ml})$ & 0.00 & 0.00 & $38.05 \pm 1.11$ \\
Females & $33.39 \pm 2.96$ & 0.00 & $19.25 \pm 1.75^{* *}$ \\
Males & $30.73 \pm 2.41$ & $38.19 \pm 4.25$ & $17.74 \pm 2.07^{* *}$ \\
\hline
\end{tabular}

Values are means \pm SEM. Significance of difference from control group: $* \mathrm{P}<0.05 ; * * \mathrm{P}<0.01$

Table 4. Caloric intake of pups ( $F 1$ animals) fed either the standard (C-M1 group, EX-M1-M1 group) or high-energy diet (EX-M1+E-M1 group) between Days 42 and 96.

\begin{tabular}{llll}
\hline $\begin{array}{l}\text { Parameter per mouse, } \\
\text { per week }\end{array}$ & $\begin{array}{l}\text { Control group } \\
\mathbf{n = 1 8}\end{array}$ & $\begin{array}{l}\text { EX-M1-M1 group } \\
\mathbf{n = 1 9}\end{array}$ & $\begin{array}{l}\text { EX-M1+E-M1 group } \\
\mathbf{n = 2 0}\end{array}$ \\
\hline $\begin{array}{l}\text { Mean caloric intake }(\mathrm{kcal}) \\
\text { Females }\end{array}$ & $72.78 \pm 4.43$ & $86.68 \pm 3.05^{*}$ & $74.88 \pm 2.97$ \\
Males & $69.41 \pm 3.54$ & $78.08 \pm 2.58$ & $71.77 \pm 5.53$ \\
\hline
\end{tabular}

Values are means \pm SEM. Significance of difference from control group: $* P<0.05$

Table 5. Analysis of blood parameters in F1 mice of control group fed standard diet (C-M1) and experimental group fed standard diet (EX-M1-M1) on Day 42.

\begin{tabular}{lll}
\hline Parameter & Control group & EX-M1-M1 group \\
\hline & $\mathrm{n}=19$ & $\mathrm{n}=20$ \\
Leptin, $\mathrm{ng} / \mathrm{ml}$ & $1.17 \pm 0.14$ & $1.39 \pm 0.16$ \\
Adiponectin, $\mathrm{ng} / \mathrm{ml}$ & $7470.8 \pm 812.92$ & $9878.3 \pm 920.11^{*}$ \\
Insulin, $\mathrm{ng} / \mathrm{ml}$ & $0.47 \pm 0.04$ & $0.55 \pm 0.08$ \\
& $\mathrm{n}=13$ & $\mathrm{n}=12$ \\
Glucose, $\mathrm{mmol} / \mathrm{l}$ & $8.34 \pm 0.15$ & $8.92 \pm 0.22^{*}$ \\
Cholesterol, $\mathrm{mmol} / \mathrm{l}$ & $1.97 \pm 0.09$ & $2.05 \pm 0.07$ \\
Triglycerides, $\mathrm{mmol} / \mathrm{l}$ & $1.64 \pm 0.06$ & $1.61 \pm 0.08$ \\
\hline
\end{tabular}

Values are means \pm SEM. Significance of difference from control group: $* \mathrm{P}<0.05$ 


\section{Discussion}

The prevalence of obesity has increased all over the world. This increase is frequently attributed to changes in life style, particularly important among them being the consumption of high-fat and high-energy diets.

From the introductory discussion it can be argued that rodent models of diet-induced obesity may provide the best parallels of much human obesity (Archer and Mercer 2007). Several distinct experimental strategies have been adopted in the study of diet-induced obesity. These strategies have compared the effect of an obesogenic diet with control diet in a single strain of rodent, the response of two rodent strains (with differential susceptibility to diet-induced obesity) to an obesogenic diet (Madiehe et al. 2000) or the range of diet-induced obesity responses to an obesogenic diet within a single strain rodent. It has been shown that the outbred rodent model exemplifies an approach whereby individual animals within the population exhibit heterogenity in their response to dietary challenge in a manner analogous to human subjects (Levin et al. 1989, Lauterio et al. 1994).

The focus of most studies of diet-induced obesity to date has understandably been on adult rodents (Mercer and Archer 2008). Very little work has been done on juvenile and early adult animals (Archer et al. 2004), despite the obvious benefits that could be derived from examination of the mechanisms underlying the development of obesity at an equivalent life stage to children and adolescents in the human population (Mercer and Archer 2008).

The Ensure Plus diet was originally used by Levin and coworkers (1998, 1999, 2002). The ability of liquid high-energy diets to stimulate overconsumption in rodents more readily than a solid diet has been described previously (Sclafani and Xenakis 1984, Sclafani 1987, Ramirez 1987). Levin and coworkers (1998, 2002) demonstrated that supplementing a solid high-energy diet with Ensure in Sprague-Dawley rats caused a sustained overconsumption of energy that resulted in increased body weight and obesity in adulthood. It has been shown that Ensure Plus induces obesity even in that proportion of the outbred population which is relatively resistant to obesity based on the pellet diet (Levin 1999, Archer et al. 2006). In our study, Ensure Plus was used for the first time as a supplement to the standard diet in mice (outbred ICR strain). Similarly as for the Sprague-Dawley rats (Archer et al. 2007), Ensure was selected in preference to a carbohydrate solution to prevent further constraint on protein availability in pregnant dams and developing mice.

Results obtained in the current study show that a model based on high-energy over-feeding of dams during pregnancy and the lactation period can be used for production of obese mice in early sexual adulthood. Supplementation of the maternal diet with Ensure Plus had no effect on general health status, body weight and body fat of dams. It positively affected their reproductive capabilities, as shown by the increased litter rate; however, this was accompanied with slightly increased mortality of pups.

In other similar studies, maternal over-feeding was rarely restricted to pregnancy and the lactation period only. Dams of C57BL/6J mice or Wistar rats were usually fed a high fat- or high-energy diet 6 to 16 weeks before mating. Such a diet resulted in increased body weight or body weight and body fat of mothers at the day of mating (Samuelsson et al. 2008, Jungheim et al. 2010, Franco et al. 2012). Besides this, it had negative effects on several reproductive parameters: obese mothers had significantly more apoptotic ovarian follicles, smaller and fewer oocytes, smaller fetuses and smaller pups (Jungheim et al. 2010).

In our study, in offspring delivered from overfed dams, significantly higher body fat deposits were already observed in male weanlings. Body fat and weight gains in pups at Day 21 probably resulted from environmental changes during their prenatal development and combined intake of breast milk and Ensure Plus during lactation period. These results support the hypothesis that higher fat and protein concentrations in the breast milk seem to induce early over-nutrition in the offspring (Franco et al. 2012).

Later, in adult animals fed the standard diet, higher deposits of body fat persisted till the last measurement at Day 96 (16th week) of their age. In contrast, adult mice fed during the first 3 weeks after weaning with Ensure Plus supplemented diet were obviously unable to compensate later for the loss of energy addition and showed significant decrease in body fat values $(\mathrm{P}<0.05$; EX-M1+E-M1 vs. EX-M1-M1).

It has been shown previously that offspring on standard (control) diet delivered from dams of C57BL/6J mice or Wistar rats or Sprague-Dawley rats fed a high-fat or high-energy diet during gestation or the gestation and lactation periods showed increased body weight and adiposity at weaning (Franco et al. 2012), increased body 
weight in males at the age of 12 weeks (Samuelsson et al. 2008) and increased body weight (Levin and Kessey 1998, Jungheim et al. 2010) or fat pad mass (Samuelsson et al. 2008) in both males and females at the age of 16 weeks. Our observations are in accordance with the majority of previous results: at weaning, the offspring delivered from the high-fat diet group had increased body weight and adiposity (Franco et al. 2012); at 16 weeks body weight did not differ significantly between controlfed offspring and high energy-fed offspring, although pups delivered in the group fed the high-energy diet were heavier despite the return to control diet by the $13^{\text {th }}$ week (Levin and Kessey 1998). Unfortunately, data on exact body fat amounts in offspring are missing in these studies.

In the majority of other studies, offspring of various ages ( 3 to12 weeks) from untreated (standard diet fed) mothers were used for dietary induction of obesity. In these studies it usually took 4 to 17 weeks to reach a significant increase in body weight or amount of body fat in male and female mice and rats fed a high-fat or highenergy diet (Archer et al. 2005, Šefč́́ková et al. 2010, Neyrinck et al. 2012, Papáčková et al. 2012, BetanzosCabrera et al. 2012). Similarly to our findings, Archer et al. $(2005,2007)$ documented that after removal of the high-energy diet, the body weight of experimental animals decreased or remained stable.

In our study, selected blood parameters were evaluated in experimental F1 mice fed standard pellet diet (i.e. in group showing unvarying development of obesity). When compared to control F1 mice, 42 days old animals with elevated body fat showed significantly higher concentrations of blood adiponectin and glucose.

Adiponectin and leptin are two important regulatory proteins produced by adipose tissue. Similarly as in our study, increase in serum adiponectin levels was documented by Bullen et al. (2007) in C57/J and A/Jmice fed high-fat diet for 10 weeks. However, these findings are in contrast with observations in humans, where the adiponectin plasma level is usually inversely correlated with body fat amount in adults (Oh et al. 2007). This might suggest age-dependent or species-specific differences in adiponectin metabolism. It has been shown that circulating adiponectin levels in mice increase abruptly by the third week of postnatal life but are relatively stable thereafter (Combs et al. 2003). However, what triggers the rise of adiponectin early in puberty is not known.

In contrast to adiponectin, circulating levels of leptin, are relatively constant from 1 to 6 weeks of age and only begin to rise by the seventh week (Ahren et al. 1997, Cheung et al. 2001).

In animal models, hyperleptinemia is usually typical consequence of high-fat diet (Levin and Kessey 1998, Tortoriello et al. 2004, Taylor et al. 2005, Archer et al. 2007). Although blood concentration of leptin tended to increase in obese mice in our study, no statistical difference with controls was found in this parameter. Similar observation was documented by Bullen et al. (2007).

In high-fat diet exposed rats, Levin and Kessey (1998) and Khan et al. (2004) documented significant increase in concentration of insulin as well. On the opposite, Archer et al. (2007) documented no differences in insulin concentrations between experimental and control groups. Similar results were found also in our study. Nevertheless, some tendency to insulin elevation (probably connected with hyperglycemia) was present.

We documented significant increase in concentration of glucose in obese mice derived in experimental group. Similar findings were documented by Khan et al. $(2003,2005)$ and Jungheim et al. $(2010)$ in studies with rats and mice. On the opposite, Levin and Kessey (1998) and Archer et al. (2007) documented no significant difference in concentration of glucose in animals subjected to high-fat diet.

In our experiment, no significant increase in concentrations of cholesterol and triglycerides was found. This is in opposite with the majority of other studies, except of Khan et al. (2005). However, this difference might explained by the different age of experimental mice. Gregersen et al. (2005) documented significant increase in triglycerides concentration and no difference in cholesterol concentration in high-fat fed rats at the age of 16 weeks. Taylor et al. (2005) documented increase in triglycerides concentration after 12 month in rats. Khan et al. (2003) documented increase of triglycerides in female rats at the age of 51 weeks.

While most rodents tend to become obese on high-fat diets, there can be variable responses in weight gain, glucose tolerance, insulin resistance, triglycerides and other parameters depending on the strain (Rossmeisl et al. 2003). Some inbred strains are more susceptible to obesity induction (C57B16, AKR mice) (Rossmeisl et al. 2003), some are more resistant (SWR/J, A/J mice) (Surwit et al. 1995, Prpic et al. 2002). This variable susceptibility to high-fat diets was observed also in populations of outbred strains, whose maintain a high 
degree of heterozygosity (Levin et al. 1997, Farley et al. 2003). Nevertheless, in our study, when experimental design described for EX-M1-M1 group was used, we were able to produce a relatively homogeneous population of outbred ICR mice displaying a significantly higher amount of body fat.

In conclusion, our results support the hypothesis that altered qualitative and quantitative nutritional conditions in prenatal and early life may have persistent effects on body weight and body condition. We standardized the animal model of obese offspring breeding based on over-feeding of mice in the preweaning period of their life, i.e. during embryonic, fetal and early postnatal development. This model produced a relatively homogeneous population of mice with a significantly higher amount of body fat, reaching the highest percentage in approximately the $6^{\text {th }}$ week of life and persisting till late adulthood. Intake of Ensure Plussupplemented diet in offspring after weaning contributed to sustaining of the value of body fat, but it did not cause its further increase. Furthermore, after withdrawal of the Ensure Plus supplement, the percentage of body fat decreased.

We conclude that the diet-induced obesity model is functional and it might be used in exploration of the effects of obesity on physiological functions of various organ systems during juvenile and early adulthood periods of life of a human being.

\section{Conflict of Interest}

There is no conflict of interest.

\section{Acknowledgements}

We thank Dana Čigašová for her technical assistance, Andrew Billingham for his English proof-reading and RIA laboratory in Košice for quantification of serum glucose, cholesterol and triglycerides. This work was supported by the Slovak Academy of Sciences under contract VEGA 2/0049/11 and the Slovak Research and Development Agency under contract APVV-0815-11.

\section{References}

AHREN BO, MANSSON S, GINGERICH RL, HAVEL PJ: Regulation of plasma leptin in mice: influence of age, high-fat diet, and fasting. Am J Physiol 273: R113-R120, 1997.

ARCHER ZA, MERCER JG: Brain response to obesogenic diets and diet-induced obesity. Proc Nutr Soc 66: 124-130, 2007.

ARCHER ZA, RAYNER DV, MERCER JG: Hypothalamic gene expression is altered in underweight but obese juvenile male Spargue-Dawley rats fed a high energy diet. J Nutr 134: 1369-1374, 2004.

ARCHER ZA, RAYNER DV, BARRETT P, BALIK A, DUNCAN JS, MOAR KM, MERCER JG: Hypothalamic energy balance gene responses in the Sprague-Dawley rat to supplementation of high-energy diet with liquid Ensure and subsequent transfer to chow. J Neuroendocrinol 17: 711-719, 2005.

ARCHER ZA, BROWN YA, RAYNER DV, STUBBS RJ, MERCER JG: Effect of flavour of liquid Ensure diet supplement on energy intake in male SD rats. Physiol Behav 89: 414-419, 2006.

ARCHER ZA, CORNELOUP J, RAYNER DV, BARRETT P, MOAR KM, MERCER JG: Solid and liquid obesogenic diets induced obesity and counter-regulatory changes in hypothalamic gene expression in juvenile SpragueDawley rats. J Nutr 137: 1483-1490, 2007.

BETANZOS-CABRERA G, ESTRADA-LUNA D, BELEFANT-MILLER H, CANCINO-DÍAZ JC: Mice fed with a high fat diet show a decrease in the expression of toll like receptor (PLR) 2 and TLR6 mRNAs in adipose and hepatic tissue. Nutr Hosp 27: 1196-1203, 2012.

BULLEN JW Jr, BLUHER S, KELESIDIS T, MANTZOROS CS: Regulation of adiponectin and its receptors in response to development of diet-induced obesity in mice. Am J Physiol 292: E1079-E1086, 2007.

CARROLL L, VOISEY J, VAN DAAL A: Mouse model of obesity. Clin Dermatol 22: 345-349, 2004.

CHAGNON YC, BOUCHARD C: Genetics of obesity: advances from rodent studies. Trends Genet 12: 441-444, 1996.

CHEUNG CC, THORNTON JE, NURANI SD, CLIFTON DK, STEINER RA: A reassessment of leptin's role in triggering the onset of puberty in the rat and mouse. Neuroendocrinology 74: 12-21, 2001.

COMBS TP, BERG AH, RAJALA MW, KLEBANOV S, IYENGAR P, JIMENEZ-CHILLARON JC, PATTI ME, KLEIN SL, WEINSTEIN RS, SCHERER PE: Sexual differentiation, pregnancy, calorie restriction, and aging affect the adipocyte-specific secretory protein adiponectin. Diabetes 52: 268-276, 2003. 
FABIAN D, MAKAREVICH AV, CHRENEK P, BUKOVSKÁ A, KOPPEL J: Chronological appearance of sponatgenous and induced apoptosis during preimplantation development of rabbit and mouse embryos. Theriogenology 68: 1271-1281, 2007.

FARLEY C, COOK JA, SPAR BD, AUSTIN TM, KOWALSKI TJ: Meal pattern analysis of diet-induced obesity in susceptible and resistant rats. Obes Res 11: 845-851, 2003.

FRANCO JG, FERNANDES TP, ROCHA CP, CALVIÑO C, PAZOS-MOURA CC, LISBOA PC, MOURA EG, TREVENZOLI IH: Maternal high-fat diet induces obesity and adrenal and thyroid dysfunction in male rat offspring at weaning. J Physiol 590: 5503-5518, 2012.

GREGERSEN S, DYRSKOG SE, STORLIEN LH, HERMANSEN K: Comparison of a high saturated fat diet with a high carbohydrate diet during pregnancy and lactation: effects on insulin sensitivity in offspring of rats. Metabolism 54: 1316-1322, 2005.

HOUSEKNECHT KL, BAILE CA, MATTERI RL, SPURLOCK ME: The biology of leptin. J Anim Sci 76: 1405-1420, 1998.

HUMMEL KP, DICKIE MM, COLEMAN DL: Diabetes, a new mutation in the mouse. Science 153: 1127-1128, 1966.

INGALLS AM, DICKIE MM, SNELL GD: Obese, a new mutation in the mouse. J Hered 41: 317-318, 1950.

JUNGHEIM ES, SCHOELLER EL, MARQUARD KL, LOUDEN ED, SCHAFFER JE, MOLEY KH: Diet-induced obesity model: Abnormal oocytes and persistent growth abnormalities in the offspring. Endocrinology 151: 4039-4046, 2010.

JURISICOVA A, ROGERS I, FASCIANI A, CASPER RF, VARMUZA S: Effect of maternal age and conditions of fertilization on programmed cell death during murine preimplantation embryo development. Mol Hum Reprod 4: 139-145, 1998.

KHAN IY, TAYLOR PD, DEKOU V, SEED PT, LAKASING L, GRAHAM D, DOMINICZAK AF, HANSON MA, POSTON L: Gender-linked hypertension in offspring of lard-fed pregnant rats. Hypertension 41: 168-175, 2003.

KHAN I, DEKOU V, HANSON M, POSTON L, TAYLOR P: Predictive adaptive responses to maternal high-fat diet prevent endothelial dysfunction but not hypertension in adult rat offspring. Circulation 110: 1097-1102, 2004.

KHAN IY, DEKOU V, DOUGLAS G, JENSEN R, HANSON MA, POSTON L, TAYLOR PD: A high-fat diet during rat pregnancy or suckling induces cardiovascular dysfunction in adult offspring. Am J Physiol 288: R127R133, 2005.

LAUTERIO TJ, BOND PJ, ULMAN EA: Development and characterization of purified diet to identify obesitysusceptible and resistant rat population. J Nutr 124: 2172-2178, 1994.

LEVIN BE: Arcuate NPY neurons and energy homeostasis in diet-induced obese and resistant rats. Am J Physiol 276: R382-R387, 1999.

LEVIN BE, DUNN-MEYNELL AA: Defense of body weight depends on dietary composition and palatability in rats with diet-induced obesity. Am J Physiol 282: R46-R54, 2002.

LEVIN BE, KESSEY RE: Defense of differing body weight set points in diet-induced obese and resistant rats. $A m J$ Physiol 274: R412-R419, 1998.

LEVIN BE, HOGAN S, SULLIVAN AC: Initiation and perpetuation of obesity and obesity resistence in rats. $A m J$ Physiol 256: R766-R771, 1989.

LEVIN BE, DUNN-MEYNELL AA, BALKAN B, KEESEY RE: Selective breeding for diet-induced obesity and resistance in Sprague-Dawley rats. Am J Physiol 273: R725-R730, 1997.

MADIEHE AM, SCHAFFHAUSER AO, BRAYMER DH, BRAY GA, YORK DA: Differential expression of leptin receptor in high- and low-fat-fed Osborne-Mendel and S5B/P1 rats. Obes Res 8: 467-474, 2000.

MERCER JG, ARCHER ZA: Putting the diet back into diet-induced obesity: diet-induced hypothalamic gene expression. Eur J Pharmacol 585: 31-37, 2008.

MODAK T, MUKHOPADHAYA: Effects of citral, a naturally occurring antiadipogenic molecule, on an energyintense diet model of obesity. J Pharmacol 3: 300-305, 2011.

MOZEŠ Š, ŠEFČÍKOVÁ Z, LENHARDT L', RAČEK L': Obesity and changes of alkaline phosphatase activity in the small intestine of 40- and 80-day-old rats subjected to early postnatal overfeeding or monosodium glutamate. Physiol Res 53: 177-186, 2004. 
NEYRINCK AM, VAN HEE VF, PIRONT N, DE BACKER F, TOUSSAINT O, CANI PD, DELZENNE NM: Wheatderived arabinoxylan oligosaccharides with prebiotic effect increase satietogenic gut peptides and reduce metabolic endotoxemia in diet-induced obese mice. Nutr Diabetes 2: e28, 2012.

OH DK, CIARALDI T, HENRY RR: Adiponectin in health and disease. Diabetes Obes Metab 9: 282-289, 2007.

PAPÁČKOVÁ Z, DAŇKOVÁ H, PÁLENÍČKOVÁ E, KAZDOVÁ L, CAHOVÁ M: Effect of short- and long-term high-fat feeding on autophagy flux and lysosomal activity in rat liver. Physiol Res 61: 67-76, 2012.

PERRY WL, COPELAND NG, JENKINS NA: The molecular basis for dominant yellow agouti coat color mutations. Bioessays 16: 705-707, 1994.

PRPIC V, WATSON PM, FRAMPTON IC, SABOL MA, JEZEK GE, GETTYS TW: Adaptive changes in adipocyte gene expression differ in AKR/J and SWR/J mice during diet-induced obesity. J Nutr 132: 3325-3332, 2002.

RAMIREZ I: Feeding a liquid diet increases energy intake, weight gain and body fat in rats. J Nutr 117: 2127-2134, 1987.

ROSSMEISL M, RIM JS, KOZA RA, KOZAK LP: Variation in type 2 diabetes-related traits in mouse strains susceptible to diet-induced obesity. Diabetes 52: 1958-1966, 2003.

SAMUELSSON AM, MATTHEWS PA, ARGENTON M, CHRISTIE MR, MCCONNELL JM, JANSEN EHJM, PIERSMA AH, OZANNE SE, TWINN DF, REMACLE C, ROWLERSON A, POSTON L, TAYLOR PD: Diet-induced obesity in female mice leads to offspring hyperphagia, adiposity, hypertension, and insulin resistance: a novel murine model of developmental programming. Hypertension 51: 383-392, 2008.

SCLAFANI A: Carbohydrate-induced hyperphagia and obesity in the rat: effect of sacharide type, form, and taste. Neurosci Biobehav Rev 11: 155-162, 1987.

SCLAFANI A, XENAKIS S: Influence of diet form on the hyperphagia-promoting effect of polysacharide in rats. Life Sci 34: 1253-1259, 1984.

ŠEFČÍKOVÁ Z, KMEŤ V, BUJŇÁKOVÁ D, RAČEK L, MOZEŠ Š: Development of gut microflora in obese and lean rats. Folia Microbiol 55: 373-375, 2010.

SURWIT RS, FEINGLOS MN, RODIN J, SUTHERLAND A, PETRO AE, OPARA EC, KUHN CM, REBUFFESCRIVE M: Differential effects of fat and sucrose on the development of obesity and diabetes in C57BL/6J and A/J mice. Metabolism 44: 645-651, 1995.

TARTAGLIA LA, DEMBSKI M, WENG X, DENG N, CULPEPPER J, DEVOS R, RICHARDS GJ, CAMPFIELD LA, CLARK FT, DEEDS J, MUIR C, SANKER S, MORIARTY A, MOORE KJ, SMUTKO JS, MAYS GG, WOOL EA, MONROE CA, TEPPER RI: Identification and expression cloning of a leptin receptor, OB-R. Cell 83: 1263-1271, 1995.

TAYLOR PD, MCCONNELL J, KHAN IY, HOLEMANS K, LAWRENCE KM, ASARE-ANANE H, PERSAUD SJ, JONES PM, PETRIE L, HANSON MA, POSTON L: Impaired glucose homeostasis and mitochondrial abnormalities in offspring of rats fed a fat-rich diet in pregnancy. Am J Physiol 288: R134-R139, 2005.

TORTORIELLO DV, MCMINN J, CHUA SC: Dietary-induced obesity and hypothalamic infertility in female DBA/2J mice. Endocrinology 145: 1238-1247, 2004.

ZHANG Y, PROENCA R, MAFFEI M, BARONE M, LEOPOLD L, FRIEDMAN JM: Positional cloning of the mouse obese gene and its human homologue. Nature 372: 425-432, 1994. 